\title{
MBA STUDENT INTERVIEWS WITH EXECUTIVES: PERSPECTIVES ON THE STRATEGIC IMPORTANCE OF INFORMATION TECHNOLOGY
}

\author{
Mark Sena, Xavier University, sena @xavier.edu \\ Gerald Braun, Xavier University, braun@ xavier.edu \\ Elaine Crable, Xavier University, crable@xavier.edu
}

\begin{abstract}
Emerging trends in the business world have led to a debate over the strategic importance of information technology (IT). This study reviews the results of 165 $M B A$ student interviews with executives regarding the strategic importance of IT in their organization. This research provides comparative perspectives on the viewpoints of IT executives and their counterparts in other management positions regarding such issues as the importance of IT, decisions about purchasing from vendors, outsourcing and offshoring, and assessing the value of IT investments. The paper also examines the educational value and the challenges of conducting these interviews.
\end{abstract}

Keywords: Information Technology (IT), CIO, IT and Executives, MBA Curriculum

\section{INTRODUCTION}

While the rise of the information era has made IT indispensable to nearly every organization, the dot com bust of the early 2000s and the prevalence of outsourcing and offshoring of jobs has led to a change in perception regarding the future of the field. The controversial article in the Harvard Business Review entitled "IT Doesn't Matter" [4] chronicled the opinion that IT is no longer a strategic differentiator between organizations due to the equality of resources among firms and the inability to gain value from IT leadership. This article has been widely criticized and debunked among IT academics and practitioners. However the negative perception of IT as a formidable career path among students has led to decreased enrollment in Information Systems and related majors across the nation.

Students, particularly those in MBA programs, desire relevant, real-world content in their coursework. For students who are also working professionals, the ability to examine how course content pertains to their work place can be even more valuable. This research describes an assignment where MBA students are asked to interview two key executives in their organization to gain their perspectives on the strategic importance of information technology. By interviewing key executives, students are able to examine these issues firsthand and have the opportunity to compare and contrast perspectives on these issues among IT and non-IT executives.

This paper describes the process of this assignment as well as the findings of the interviews. While the assignment is not without a few challenges, it is quite beneficial to most students and to instructors.

\section{BACKGROUND}

Student interviews focused on three primary concerns of strategic interest to IT: 1) how important is IT to the success of a business especially as it pertains to competitive advantage within a particular industry; 2) do IT initiatives result in a positive return on investment and can expenditures be measured and justified; and 3) to what extent are companies moving to packaged software and outsourcing/offshoring as a means to reduce IT expenditures.

Carr [4] contends that because of the ubiquitous nature of modern IT initiatives, IT is no longer strategically important to the business. Companies "only gain an edge over rivals by having or doing something that they can't have or do." In a follow-up issue of the HBR, "Does IT Matter? An HBR Debate," several letters to the editor contest Carr's assertions. Brown and Hagel [3] contend that while "IT by itself rarely, if ever, confers strategic differentiation...IT is inherently strategic because of indirect effects...The differentiation is not IT itself, but in the new practices it enables." McFarlan and Nolan [7] see IT initiatives such as grid computing and open systems as enabling technologies to "provide a stable platform to build on (offering) new ways of differentiating" rather than stifling differentiation. Broadbent et. al [2]., contend that "the source of competitive advantage (has) shifted from having a computer to knowing how to use it." Skaistis [9] states that "IT can provide significant strategic and competitive benefits for an organization - but only when it is used effectively."

On the second point, Carr [4] encourages companies to delay IT investments because "studies of corporate 
IT spending consistently show that greater expenditures rarely translate into superior financial results." In general, the literature supports the notion that IT initiatives do not necessarily lead to a positive return on investment. A McKinsey Global Institute study on "U.S. Productivity Growth for 1995 to 2000" [3] found a positive correlation between IT investments and productivity in only 6 of 59 industries. Strassmann [10] contends that his research confirms that "profitability and IT spending are unrelated." Brown and Hagel [3] see IT's economic impact coming from incremental innovations rather than "big bang" initiatives. According to Morgan and Gary [8], companies reduced IT spending in 2001 by $8.4 \%$. However, a later poll of 250 senior finance executives indicated a surprising consensus on the ultimate potential of IT [5]. Three-fourths of the respondents considered IT to be strategic and $60 \%$ of those plan to spend more on IT in 2005. However, fewer than half of all respondents believed that IT expenditures achieved the return they had expected. In a 2004 study [6] $51 \%$ of 182 survey respondents increased 2004 budgets from 2003 levels and $43 \%$ of 2005 budgets will be greater than in 2004. Brennan [1] contends that return on IT investments is a primary concern and appropriate measures are necessary to "distinguish fads from substance." $\mathrm{He}$ sees the biggest pitfall in IT decision making is embracing a solution without fully understanding the underlying needs.

On the third point, Carr [4] advocates the use of packaged rather than proprietary software, and outsourcing to cut IT costs. There is no doubt that enterprise resource solutions and outsourcing are of interest to many companies. However, according to Strassmann [10] generic applications are useful for routine business processes but can destroy a firm trying to "squeeze unique company processes into generic molds." Furthermore, Luftman [6] found that only $32 \%$ of survey respondents were using offshore outsourcing in 2004. Of the respondents, $82 \%$ reported less than $10 \%$ of outsourcing was being done offshore. Outsourcing, and more ominously, offshore outsourcing, may be a fact of life for IT professionals, but it is by no means as widespread as some people imagine. According to the Luftman study [6], 77\% of respondents expected the same or increased headcount in 2004 from 2003.

Despite the considerable evidence in refute of Carr, there are certainly shreds of truth in his arguments. The relative importance of IT in particular organizations can vary widely. Thus, an exercise of this nature helps students to understand the position of their organizations on these subjects and, collectively, have the opportunity to compare and exchange views with other students.

\section{INTERVIEW PROCESS AND REQUIREMENTS OF ASSIGNMENT}

The executive interview assignment was conducted at a large, predominantly part-time MBA program located in a mid-western city. The assignment is part of the core information technology course that is required of all students. Most students in the course are not IT professionals but work in professional positions that require use of IT.

Students are first introduced to the assignment via the course syllabus and the ensuing discussion on the first day of class. The following description appears in the course syllabus:

Interview your CEO (or a key manager in your organization) and your CIO (or key Information Systems official in your organization) regarding the strategic importance of IT in their organization. Solicit their opinions by asking them to strongly agree(5), agree(4), neutral(3), disagree(2), or strongly disagree(1) with the following statements:

- Information Technology is very important to the strategic success of our organization

- Our use of IT helps differentiate us from our competitors

- Most of our investments in IT have resulted in positive return on investment

- In examining new information systems, we typically seek to purchase solutions rather than develop them in-house

- We are looking increasingly at outsourcing many of our IT functions

- We are looking increasingly to reduce costs by using offshore IT outsourcing

- We have implemented mechanisms that effectively measure and justify IT expenditures

At the conclusion of the interview, summarize each of the interviews, then compare and contrast the perspectives recorded. Finally, include your personal reaction to this assignment in your report. This will be 3-4 single-spaced word-processed papers.

Note: if you are unable to conduct such an interview (full time student, very small organization, etc.), you may request to have the points for this assignment added to the research paper (with a proportionate increase in length and quality expected). 
This assignment, in various forms, has been presented to over 150 students in seven course sections over the past year. Initially, the assignment in previous years required only qualitative responses. The scaled responses were added to allow the instructor to tabulate statistics and share the collective results with students and also to enhance the potential to use the data for research purposes. In the first term, when students were unable to conduct interviews for various reasons (full time student, work for small company or one without significant IT expenditures, etc.), efforts were made to arrange interviews with university executive staff. Eventually, this became a burden to instructors resulting in the last statement in the figure where students are allowed to allocate the points from the interview to another assignment. However, to encourage students to conduct the interview, this is only offered on an exception basis and students must initiate the process. Nearly $95 \%$ eventually conduct the interviews.

Grading the resulting papers can be challenging. It can be difficult to separate the quality of student efforts in interviewing, reporting, and analyzing responses from the content of the responses given by the subjects. Instructors are reluctant to penalize (or reward) students for the opinions of their interviewees. As a result, we have reduced the value of the assignment to just $10 \%$ of the total course grade. Thus, while the assignment is a valuable learning experience, it comprises a relatively modest portion of the total grade. The grading of the assignment is based on the following factors:

- Paper describes the job titles, department, nature of responsibilities for both the IT and Managerial interviewees.

- Interview summaries indicate that all appropriate questions were asked and that the student sought complete, satisfactory answers.

- Paper was easy to read, well organized, free from grammatical errors, professional in appearance.

- Analysis and conclusions not only compared and summarized results but also added insights and reflection beyond the answers provided.

Instructors must also be flexible with this assignment. Since students must arrange interviews with executives with busy schedules, it is possible that students may need extensions on deadlines or alter who they plan to interview. Confidentiality must also be stressed. Students are encouraged to electronically share their findings but without revealing the company or executive names. Similarly, the instructor must emphasize that while the collective results may be shared, individual opinions are completely confidential.

\section{RESULTS AND LEARNING OUTCOMES}

Unsolicited, anecdotal responses have been quite positive. The following are a collection of quotes from students regarding the interview assignment:

- "This project was truly enlightening for me."

- "I believe this assignment gave me the opportunity to truly understand the ideals regarding technology within the organization in which I work.... Additionally, this assignment allowed me to take concepts learned in class and reexamine them in a context that is more personally related to me."

- "I found it very interesting to get the opinions of these executives at my organization... because I do not work at the headquarters location for my company. A lot of the ideas expressed by both gentlemen were things I had not realized working for this company for the past two years."

- "Overall, these interviews were very valuable to my understanding of my company. Perhaps more important is the fact that I was able to sit down with two individuals who are very high up in the organization, learn from them and network with them."

This and other feedback from students indicate that the assignment is effective in helping students to understand current perspectives on strategic IT. Furthermore, by conducting the interviews, students were able to establish a dialog with two key executives in their organization whom they may not otherwise have had the opportunity to interact with, particular in regards to the subject area. In some cases the MBA student was asked to do company presentations of their final paper report to an executive group. Similarly, by reading the various interview reports, instructors are able to gain insights into the viewpoints of executives whose organizations hire their students, help to fund the business school, and provide feedback to shape curricular decisions.

While the major learning outcome of the assignment involves the experience of students learning from executives at their particular organization, by examining the collective results, students can gain an understanding of how their results compare to others and gain an appreciation of trends in the region. As shown in Table 1, there are some interesting results from the survey data. The table identifies the overall 
mean of each item from IT executives and non-IT executives. We also present two statistical computations, a paired t-test and paired samples correlation, to compare the corresponding results (recall that the data includes paired interviews from an IT executive and a non-IT executive within the same organization).

Table 1. Executive Responses to Strategic Importance of IT Interviews

\begin{tabular}{|c|c|c|c|c|}
\hline \multirow{2}{*}{\multicolumn{2}{|c|}{ Interview Question }} & \multirow{4}{*}{$\begin{array}{l}\text { Mean } \\
4.80 \\
4.63\end{array}$} & \multicolumn{2}{|c|}{ Paired Samples } \\
\hline & & & \multirow{3}{*}{$\frac{\text { t-test }}{2.45^{*}}$} & \multirow{3}{*}{$\begin{array}{l}\text { Correlation } \\
.53 * *\end{array}$} \\
\hline \multirow{2}{*}{$\begin{array}{l}\text { Information Technology is very important to the strategic } \\
\text { success of our organization }\end{array}$} & IT EXEC & & & \\
\hline & NON-IT EXEC & & & \\
\hline \multirow[t]{2}{*}{ Our use of IT helps differentiate us from our competitors } & IT EXEC & 4.09 & \multirow[t]{2}{*}{1.37} & \multirow[t]{2}{*}{$.55^{* *}$} \\
\hline & NON-IT EXEC & 3.96 & & \\
\hline \multirow{2}{*}{$\begin{array}{l}\text { In the past, most of our investments in IT have resulted in } \\
\text { positive return on investment }\end{array}$} & IT EXEC & 3.88 & \multirow[t]{2}{*}{$2.47^{*}$} & \multirow[t]{2}{*}{.17} \\
\hline & NON-IT EXEC & 3.54 & & \\
\hline \multirow{2}{*}{$\begin{array}{l}\text { We have implemented mechanisms that effectively } \\
\text { measure and justify IT expenditures }\end{array}$} & IT EXEC & 3.62 & \multirow[t]{2}{*}{0.99} & \multirow[t]{2}{*}{$.48^{* *}$} \\
\hline & NON-IT EXEC & 3.43 & & \\
\hline \multirow{2}{*}{$\begin{array}{l}\text { In examining new information systems, we typically seek } \\
\text { to purchase solutions rather than develop them in-house }\end{array}$} & IT EXEC & 3.79 & \multirow[t]{2}{*}{1.49} & \multirow[t]{2}{*}{$.50^{* *}$} \\
\hline & NON-IT EXEC & 3.62 & & \\
\hline \multirow{2}{*}{$\begin{array}{l}\text { We are looking increasingly at outsourcing many of our IT } \\
\text { functions }\end{array}$} & IT EXEC & 2.88 & \multirow[t]{2}{*}{-0.53} & \multirow[t]{2}{*}{$.71^{* *}$} \\
\hline & NON-IT EXEC & 2.97 & & \\
\hline \multirow{2}{*}{$\begin{array}{l}\text { We are looking increasingly to reduce costs by using } \\
\text { offshore IT outsourcing }\end{array}$} & IT EXEC & 2.73 & \multirow[t]{2}{*}{0.52} & \multirow[t]{2}{*}{$.19^{*}$} \\
\hline & NON-IT EXEC & 2.64 & & \\
\hline
\end{tabular}

$\mathrm{n}=165$ (83 IT Executive, 82 Non-IT Executive Responses)

5-point Likert-scale where 5=strongly agree, 4=agree, $3=$ neutral, $2=$ disagree, $1=$ strongly disagree

$*$ p-value $<.05 ; * *$ p-value $<.01$

While responses from IT executives were statistically higher than responses from other executives concerning the importance of IT to the strategic success of the organization, the high mean values suggest that IT remains very important. The correlation coefficient suggests overall agreement on this issue. Similarly, there was agreement (based on the lack of statistical difference in the t-test of means and the positive correlation) that IT serves as a differentiator between competing firms. In examining the magnitude of the mean responses, it would seem that executives tend to disagree with Carr's assertion that IT is not competitively important. Qualitative responses support these statistical findings. For example, one interview, in the retail pharmaceutical industry, reported that their organization's superiority in IT played a major role in the demise of a competing firm.

IT respondents were also more likely to agree that past investments in IT have lead to a positive ROI. This is not surprising, given the stake that IT professionals have in the success or failure of IT projects. Agreement as to an organization's ability to measure and justify IT expenditures is mixed. There is no statistical difference in the mean of the paired samples, but the lack of a significant correlation suggests that there may be uncertainty regarding whether organizations have sufficiently implemented methodologies to measure and assess the value of IT investments.

In general, both types of executives agree that purchased solutions rather than in-house developed solutions are preferred. In examining the frequencies of this item, we learn that only $13 \%$ of executives support in-house development (e.g., disagreed or strongly disagreed with the statement). This insight could lead to a discussion about IT curricula, which tend to focus heavily on development skills with less focus on vendor relationships, implementation techniques, change and configuration management, etc.

The mean value for the last two questions suggests that there is only a moderate trend toward future outsourcing and offshoring. Regarding general outsourcing of IT, both types of executives were in strong agreement with a high correlation and an insignificant difference in mean. The data on the offshoring item was similar but with only a modest correlation which suggests that there may be less 
certainty within organizations regarding future offshoring plans.

\section{CONCLUSIONS}

Overall, the interviews have been a success from both the student and the instructor perspectives. We intend to continue the process in coming terms. Students seem to enjoy the project. It gives them an opportunity to discuss real issues with real executives. From the professor's viewpoint, the project provides another mechanism for interaction and feedback from the business community concerning strategic IT issues. This serves to extend and enhance classroom discussion about these issues for both current and future classes.

We feel this methodology could easily be extended to other disciplines. For example, students in a marketing or finance course, or another IT course could interview professionals in their organizations regarding emerging trends in those disciplines. While the assignments of this nature are likely to be more feasible in courses with predominantly working professionals, interviews could be an effective technique that could be deployed in undergraduate courses as well. This paper describes one methodology for student-executive interviews. Future research could focus on comparing and contrasting the benefits and drawbacks of student interviews to identify best practices that other instructors could use in their courses.

Finally, this study provides a broad view of the trends and perspectives in the current IT industry. While this research, due to its methodology, may lack the rigor necessary to make conclusive findings regarding the statistical relationships presented, the viewpoints captured in these interviews include some of the most influential decision makers in our region. As such, the data provides a foundation to explore more detailed study of these or related issues.

\section{REFERENCES}

1. Brennan, J., (2002). Show me the value, CIO Magazine, [online] Available: http://www.cio.com/archive/050102/perspective. $\underline{\mathrm{html}}$

2. Broadbent, M., McDonald, M., \& Hunter, R. (2003). Letters to the editor, Does IT matter? An HBR debate. Harvard Business Review, 81(7), 10.

3. Brown, J. S. \& Hagel III, J. (2003). Letters to the editor, Does IT matter? An HBR debate. Harvard Business Review, 81(7), 2-4.

4. Carr, N.G. (2003). IT doesn't matter. Harvard Business Review, 81(5), 41-49.

5. Leibs, S. (2004). One way or another: CFOs agree on the value of IT but disagree on how to measure and manage it. CFO, 20(15), 18-23.

6. Luftman, J. (2004). Key issues for IT executives. MIS Quarterly Executive, 4(2), 269-285.

7. McFarlan, F. W. \& Nolan R. L. (2003). Letters to the editor, Does IT matter? An HBR debate. Harvard Business Review, 81(7), 5.

8. Morgan, N. \& Gary, L. (2002). Should you fire your CIO? Harvard Management Update, 17(7), 8-9.

9. Skaistis, B. (2003). Letters to the editor, Does IT matter? An HBR debate. Harvard Business Review, 81(7), 11.

10. Strassmann, P. A. (2003). Letters to the editor, Does IT matter? An HBR Debate. Harvard Business Review, 81(7), 7-9. 